\title{
Diving behavior and delayed mortality of olive ridley sea turtles Lepidochelys olivacea after their release from longline fishing gear
}

\author{
Yonat Swimmer ${ }^{1, *}$, Randall Arauz ${ }^{2}$, Marti McCracken ${ }^{1}$, Lianne McNaughton ${ }^{3}$, \\ Jorge Ballestero ${ }^{2}$, Mike Musyl ${ }^{3}$, Keith Bigelow ${ }^{1}$, Richard Brill ${ }^{4}$ \\ ${ }^{1}$ National Marine Fisheries Service, Pacific Island Fisheries Science Center, 2570 Dole Street, Honolulu, Hawaii 96822 \\ ${ }^{2}$ PRETOMA, 120-1100 Tibás, San José, Costa Rica \\ ${ }^{3}$ Joint Institute for Marine and Atmospheric Research, University of Hawaii, 1000 Pope Road, Honolulu, Hawaii 96822, USA \\ ${ }^{4}$ Virginia Institute of Marine Science and National Marine Fisheries Service, 1208 Greate Road, Gloucester Point, \\ Virginia 23062, USA
}

\begin{abstract}
We deployed pop-off satellite archival tags (PSATs) on 14 olive ridley turtles Lepidochelys olivacea and 1 green turtle Chelonia mydas in the eastern tropical Pacific Ocean between November 2001 and June 2003 to determine dive behavior and post-release mortality following interactions with longline fishing gear. Nine olive ridleys and 1 green turtle were captured by longline fishing gear, and 5 free swimming olive ridleys were hand-captured at the surface to serve as controls. Hooks were removed from all longline-caught turtles, with the exception of 1 olive ridley turtle. PSATs remained on control- and longline-caught olive ridleys for an average of 61 and $54 \mathrm{~d}$, respectively (range: 26 to 115) and on the green turtle for $26 \mathrm{~d}$. Olive ridleys spent nearly all of their recorded time within the top $60 \mathrm{~m}$, with very few dives exceeding $100 \mathrm{~m}$. Over $95 \%$ of the time was spent between water temperatures of 22 and $28^{\circ} \mathrm{C}$ and turtles' dive behaviors appeared to be correlated with oceanographic variables (e.g. sea surface temperature and chlorophyll concentration). There were no clear differences evident either in horizontal movements, depth distributions, or associations with specific water temperatures between longline-caught and control turtles. Our data showed only one mortality event, that of a control turtle that died and sank $66 \mathrm{~d}$ after being tagged. We conclude that olive ridley turtles that are lightly hooked and handled properly survive and generally behave normally following interactions with shallow-set longline gear.
\end{abstract}

KEY WORDS: Marine turtles · Pop-off satellite archival tags $\cdot$ PSATs $\cdot$ Eastern tropical Pacific Ocean Resale or republication not permitted without written consent of the publisher

\section{INTRODUCTION}

The incidental capture of marine turtles by pelagic longline fishing gear occurs worldwide. Most interactions occur with shallow-set gear targeting swordfish Xiphias gladius, mahimahi Coryphaena hippurus or yellowfin tuna Thunnus albacares, although sea turtles are occasionally caught by deep set (>100 m) longline gear targeting fish of high commercial value fish such as bigeye tuna T. obesus (Ferreira et al. 2001, Polovina et al. 2002). Hard-shelled loggerhead Caretta caretta and olive ridley Lepidochelys olivacea turtles are opportunistic feeders and generally bite baited hooks, whereas leatherback turtles Dermochelys coriacea are most often hooked in the flippers or simply become entangled (Witzell 1999), likely as a result of having been drawn into the vicinity of the fishing gear.

Nearly all sea turtles incidentally caught on shallowset gear are alive at retrieval (Witzell 1999). There is, however, the potential for high rates of post-release mortality especially when turtles are released with hooks or lines remaining in their mouths, throats, gastrointestinal tracts, or flippers that can lead to infection (Aguilar et al. 1995, Chaloupka et al. 2004). More- 
over, it has been suggested that longline interactions may be contributing to the global decline in sea turtle populations (Spotila et al. 2000, Hays et al. 2003). For this reason, understanding and ultimately predicting the ultimate fate of released turtles is of growing importance to marine resource managers worldwide.

The assessment of post-release mortality following interactions with longline fishing gear has been difficult and current estimates for loggerhead and leatherback turtles range from 8 to $95 \%$ (Aguilar et al. 1995, McCracken 2000, Chaloupka et al. 2004). These estimates are based on the fraction of turtles that were dead upon retrieval of the gear, observed mortalities in turtles captured on longlines and subsequently held in tanks for direct observations (Aguilar et al. 1995), and cessation of transmissions of satellite platform terminal transmitters (PTTs) (Hays et al. 2003, Chaloupka et al. 2004). However, use of PTT data is not optimal for determining mortality because cessations of transmission can not be clearly ascribed to a mortality, tag shedding, or electronics failure (Chaloupka et al. 2004, Hays et al. 2004). Data from fisheries observers have also been used to estimate post-release mortalities, whereby turtles are grouped based on the extent of their injuries, and the groups are assigned a probability of mortality (McCracken 2000). The definitions of these groups and the corresponding mortality estimates remain contentious.

The objectives of our study were 2-fold: to identify mortality of sea turtles following release from longline fishing gear, and to look for indications of the severity of sustained injuries by comparing the vertical and horizontal movements of sea turtles released from longline gear with control turtles. We used pop-up satellite archival tags (PSATs) to accomplish these goals because these devices are designed to record dive depths and ambient water temperatures and to provide a daily estimate of geolocation. Originally designed to track the movement of large pelagic fish (Lutcavage et al. 1999, Arnold \& Dewar 2001), they have also been successfully employed to estimate postrelease mortality in pelagic fishes (Arnold \& Dewar 2001, Graves et al. 2002) and their use has been specifically recommended to measure post-release mortality of pelagic sea turtles (Chaloupka et al. 2004). Specifically, the advantages of PSATs over PTTs is that they can be programmed to detach and transmit archived data if they reach depths (usually $>1200 \mathrm{~m}$ ) well below dive depths for all species of hard-shelled sea turtles (Lutcavage \& Lutz 1997), that are indicative of a mortality. Alternatively, PSATs can be programmed to detach and transmit archived data if they experience no change in depth for 4 consecutive days (e.g. the turtle dies over shallow area such as the continental shelf, or the tag has been shed prematurely and is floating on the surface). The transmitted depth record can be used to differentiate these alternatives.

\section{MATERIALS AND METHODS}

Animal capture and PSAT attachment procedures. Working in collaboration with local commercial longline fishermen between November 2001 and June 2003, we deployed PSATs on 9 olive ridley turtles and 1 green sea turtle Chelonia mydas incidentally caught on fishing gear during 5 longline cruises in the Gulf of Papagayo off the Pacific Coast of Costa Rica. Hook types were not uniform, as Costa Rican fishermen use number 13 and 14 circle hooks, with or without 10 degree offset (these specifics were not recorded). Eight of the olive ridley turtles were hooked in the jaw or mouth, and the hooks were removed prior to release. For the other olive ridley turtle, the hook eye was visible at the back of the throat but hook removal would have caused extensive injury to the turtle due to its location in the esophagus, and the hook was thus left in place. To serve as controls, we also hand captured 5 free-swimming olive ridley turtles as they rested at the surface. They were brought aboard the research vessels, PSATS were attached, and they were immediately released.

For 13 of the 15 tags, we employed a tether and baseplate system (described by Swimmer et al. 2002) to attach the PSATs. The tethers (holding the PSAT to the baseplate) were constructed from $270 \mathrm{lb}(123 \mathrm{~kg})$ test fluorocarbon fishing line terminated with a stainless steel swivel. Stainless steel crimps (Nicopress), matched to the diameter of the fluorocarbon line, were used to form the required loops. The baseplates were constructed from syntactic foam (Syntech Materials) shaped into rounded discs (approximately $7 \mathrm{~cm}$ diameter and $2 \mathrm{~cm}$ thick at the center). They were placed on lateral scutes $\mathrm{L}_{4}$ or $\mathrm{L}_{5}$ and held in place with marine epoxy (Marine Fix ${ }^{\circledR}$ Fast, Eclectic Products). We chose syntactic foam as a base plate material because it retains buoyancy even when subjected to the pressures at $2500 \mathrm{~m}$ depth. We chose this particular brand of epoxy because it is easy to use, water-resistant, and hardens within $1 \mathrm{~h}$. Furthermore, we found base plates attached with epoxy would remain on green sea turtles held in captivity for up to $1 \mathrm{yr}$ with no obvious adverse effects to the animals (Swimmer et al. 2002).

For the remaining 2 turtles, we attached the PSAT tether to a stainless steel U-bolt that was placed through 2 holes (approximately $0.4 \mathrm{~cm}$ in diameter) drilled in the postcentral scutes as described by Epperly et al. (2002).

Data collection and analysis procedures. We used pop-off tags from 2 manufactures: Wildlife Computers 
(model PAT) and Microwave Telemetry (model PTT100). Wildlife Computer (WC) tags were programmed using PATHOST software to record pressure (i.e. depth, $\mathrm{m})$, light level, and temperature $\left({ }^{\circ} \mathrm{C}\right)$ every $60 \mathrm{~s}$, and to store the data in 12 depth and temperature bins covering ranges from 0 to $1000 \mathrm{~m}$ and 5 to $60^{\circ} \mathrm{C}$, respectively. They were also programmed to record maximum daily dive depth and to release from the animal $1 \mathrm{yr}$ after deployment. Microwave Telemetry (MT) tags were programmed to acquire temperature and pressure (depth) readings every hour and to release from the animal $8 \mathrm{mo}$ after deployment. Daily geolocation estimates were obtained using the light and temperature data from the WC tags and using manufacturer-supplied software. For the MT tags, estimates for dawn and dusk were automatically calculated onboard the tag by a proprietary algorithm, and estimates of daily geolocations were supplied by the tag manufacturer (Gunn \& Block 2001).

In order to differentiate a mortality event from a shed tag, MT tags were programmed to release from the animal and transmit data when they reached $1200 \mathrm{~m}$. This was based on the observation that turtles that die in captivity initially sink. The tags were also programmed to release and transmit data if they did not experience significant pressure changes for 4 consecutive days (i.e. they were shed and floating on the surface, or the turtle had died and sunk to a depth of less than $1200 \mathrm{~m}$ ). Likewise, WC tags were fitted with a thimble-like release device (RD1500), whereby a piston was set to crush and sever the monofilament tether at 1500 to $1800 \mathrm{~m}$ if a turtle died and sank.

Because the 2 types of tags functioned differently, data were compiled in 3 different ways: (1) temperature and depth data collected by the MT tags were compiled into $2^{\circ} \mathrm{C}$ and $20 \mathrm{~m}$ bins (respectively). (2) Median daily depths and associated water temperatures of individual turtles recorded over time were plotted by fitting a smoother to the data over each day, night, and daily ( $24 \mathrm{~h}$ ) period. Statistical analyses were not performed on these data due to the high variability among turtles; trends are, however, reported. (3) Turtle 'groups' (control vs. longline-caught) were formed that enabled qualitative comparisons.

Two-sample $t$-tests were used to compare the horizontal movements (straight line distance) of longlinecaught $(\mathrm{N}=7)$ vs. control $(\mathrm{N}=4)$ turtles for the duration of their time at liberty (start and end points), and the retention times of tags. Maximum dive depths were also determined for each turtle, and the influence of lunar illumination (e.g. variance in light from new to full moon, not corrected for cloud cover) and turtle size (curved carapace length) were investigated for each turtle using correlation analysis.

\section{RESULTS}

Details of turtle size, sex, injuries, and minimum distance traveled are given in Table 1.

Of the 15 tags deployed, all but 3 reported data (1 WC tag and 2 MT tags did not report). Two of the nonreporting PSATs were attached to longline-caught and one to a control turtle. There was no difference $(t=$ $0.428, \mathrm{p}>0.60$ ) in the times (mean $\pm \mathrm{SE}$ ) PSATs remained on control ( $60 \pm 7 \mathrm{~d}$, range $=39$ to $72 \mathrm{~d}$ ) or longline-caught turtles $(54 \pm 10 \mathrm{~d}$, range $=26$ to $115 \mathrm{~d})$. The one PSAT on a green turtle remained attached for $26 \mathrm{~d}$.

\section{Horizontal movements}

The start and end points for all tracks are shown in Fig. 1 and represent the shortest possible distances traveled. Longline-caught and control olive ridley turtles showed the same average distance traveled $(t=$ $-0.06, \mathrm{p}>0.90)$. The former moved on average $262 \pm 51$

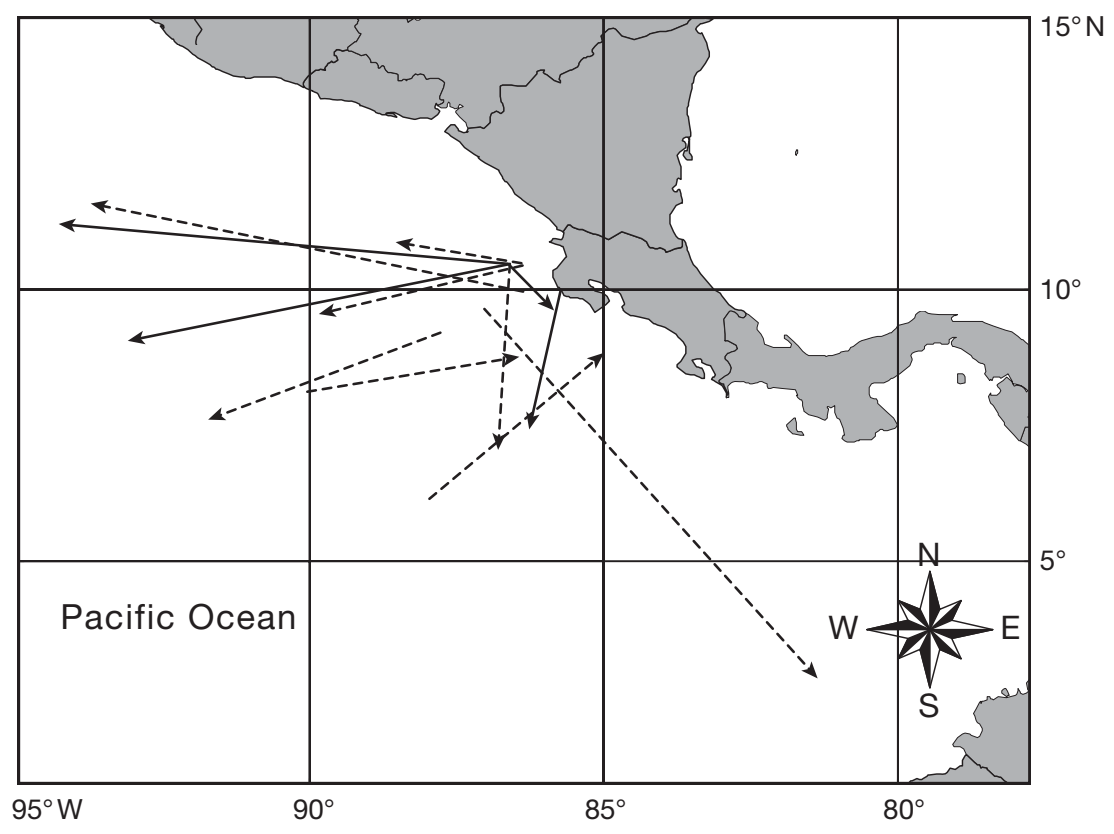

Fig. 1. Lepidochelys olivacea. Movements of 7 olive ridley turtles and 1 green turtle (dashed lines) after release from longline fishing gear, and of 4 olive ridley turtles (controls) that were free-swimming prior to tagging (solid lines). Lines represent shortest possible distances between pop-up satellite tag deployments and the tags' locations after being released from the animals and are not intended to indicate turtles' movements 


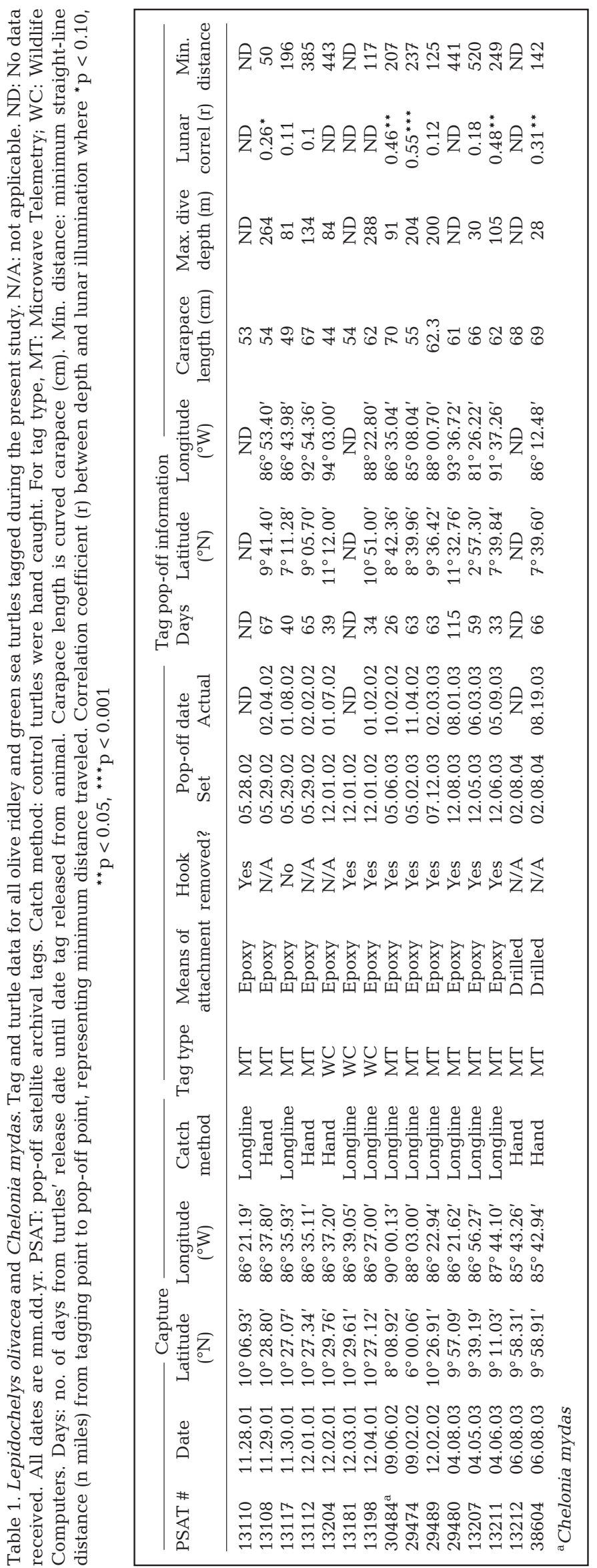

(SE) nautical miles ( $\mathrm{n}$ miles; range $=117-520 \mathrm{n}$ miles) and the latter $255 \pm 94 \mathrm{n}$ miles (range $=50-443 \mathrm{n}$ miles). The average distance traveled per day $( \pm \mathrm{SE})$ was the same for both longline-caught and control turtles $(5.3 \pm 0.9 \mathrm{n}$ miles and $5.0 \pm 2.4 \mathrm{n}$ miles, respectively; $\mathrm{t}=-0.14 ; \mathrm{p}>0.40$ ). The single green turtle traveled a distance of $207 \mathrm{n}$ miles at an average speed of $8.0 \mathrm{n}$ miles $\mathrm{d}^{-1}$.

\section{Vertical movements}

Control turtles spent $92 \%$ and longline-caught turtles $78 \%$ of the recorded daytime hours at a depth less than $60 \mathrm{~m}$. Control turtles never descended below $100 \mathrm{~m}$ during the day, while longline-caught turtles made numerous daytime dives beyond $100 \mathrm{~m}$, reaching maximum depths of $340 \mathrm{~m}$ (Fig. 2). Both control and longline-caught turtles appeared to remain closer to the surface during the night than during the day; at night $94 \%$ of the recorded time was spent above $60 \mathrm{~m}$ (Fig. 2). Control turtles, however, made deep dives during the night, and $>2 \%$ of their recorded nighttime

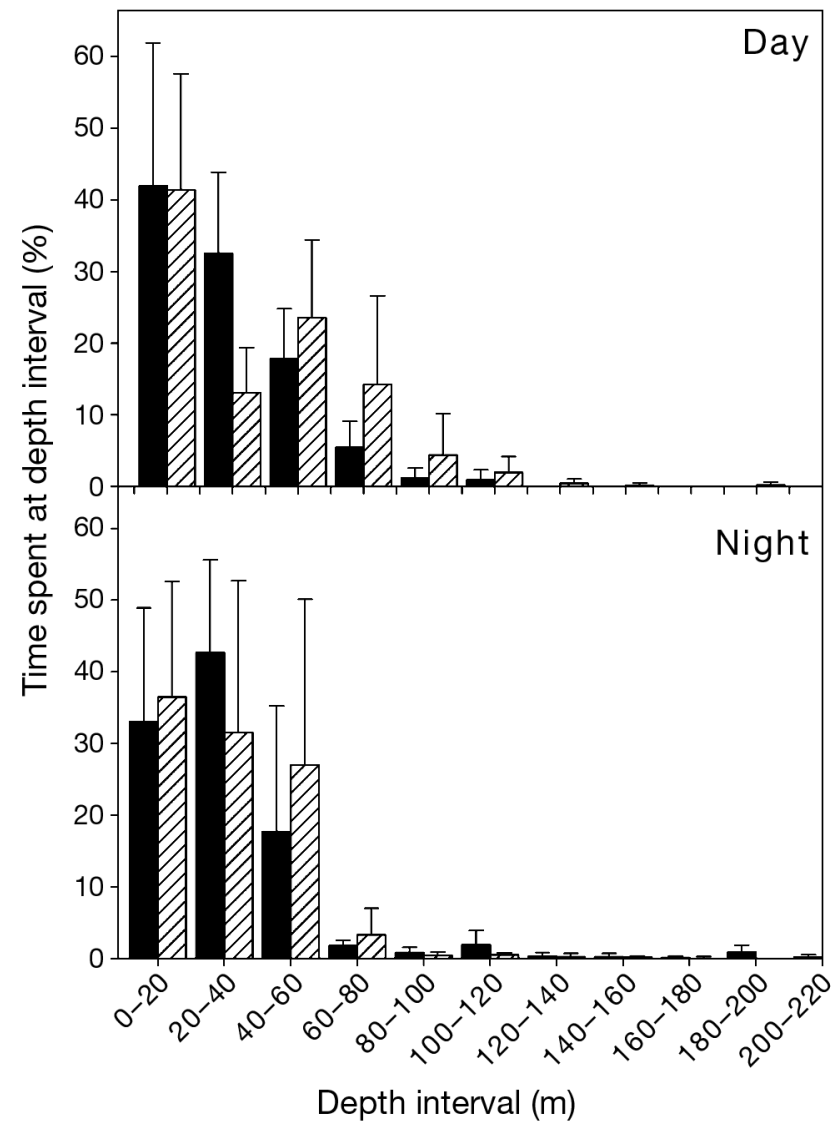

Fig. 2. Lepidochelys olivacea. Depth distributions $( \pm \mathrm{SE})$ of 7 olive ridley turtles released from longline fishing gear (filled bars) and 4 control turtles (striped bars) 
depths were between 120 and $300 \mathrm{~m}$ (Fig. 2). Interestingly, both the deepest and the shallowest distribution within the tracking period was recorded for 2 longlinecaught turtles (Figs. 3 \& 4).

Average depth of daily maximum dives $( \pm \mathrm{SE})$ were the same for longline-caught turtles $(214 \pm 55 \mathrm{~m}$; range $=81$ to $408 \mathrm{~m})$ and control turtles $(150 \pm 42 \mathrm{~m}$; range $=$ 84 to $264 \mathrm{~m})(t=0.844 ; \mathrm{p}>0.50)$. Turtle size, based on curved carapace length, was only slightly positively correlated with maximum dive depth $(\mathrm{r}=0.08)$. Smoothed median daily depths by days post-capture and by day of the year are presented in Figs. $3 \& 4$, respectively.

Longline-caught turtles spent $60 \%$ and control turtles $76 \%$ of the daylight hours between 24 and

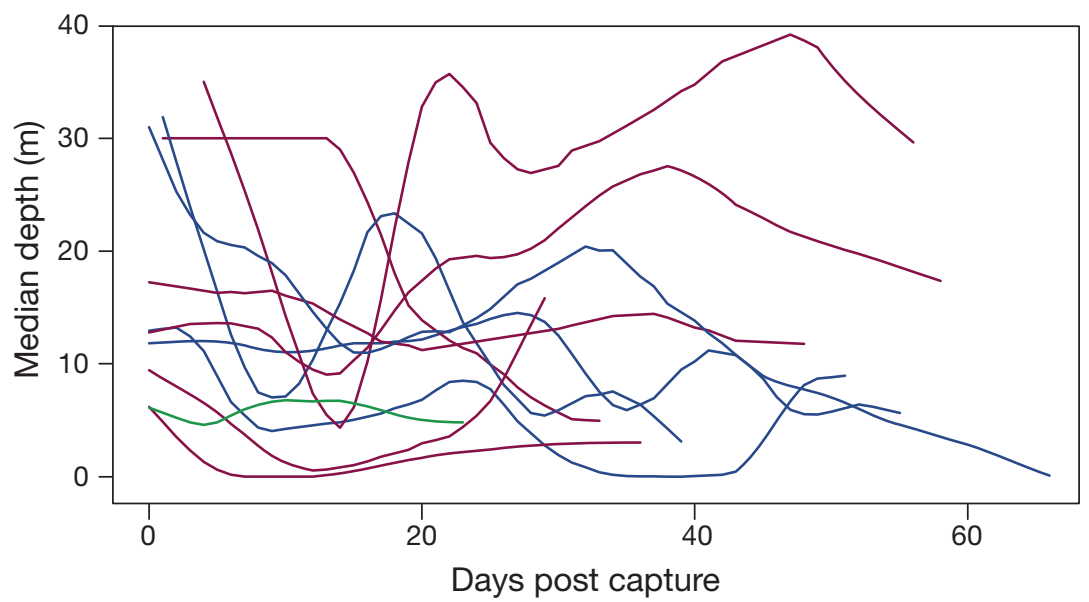

Fig. 3. Lepidochelys olivacea. Smoothed median daily depths of turtles. Day of capture and release for each turtle is set at 0 . Daily median depths are shown for 3 turtle groups: longline-caught olive ridley turtles $(\mathrm{n}=6$; red), olive ridley 'control' turtles ( $\mathrm{n}=4$; blue), longline-caught green turtle ( $\mathrm{n}=1$; green)

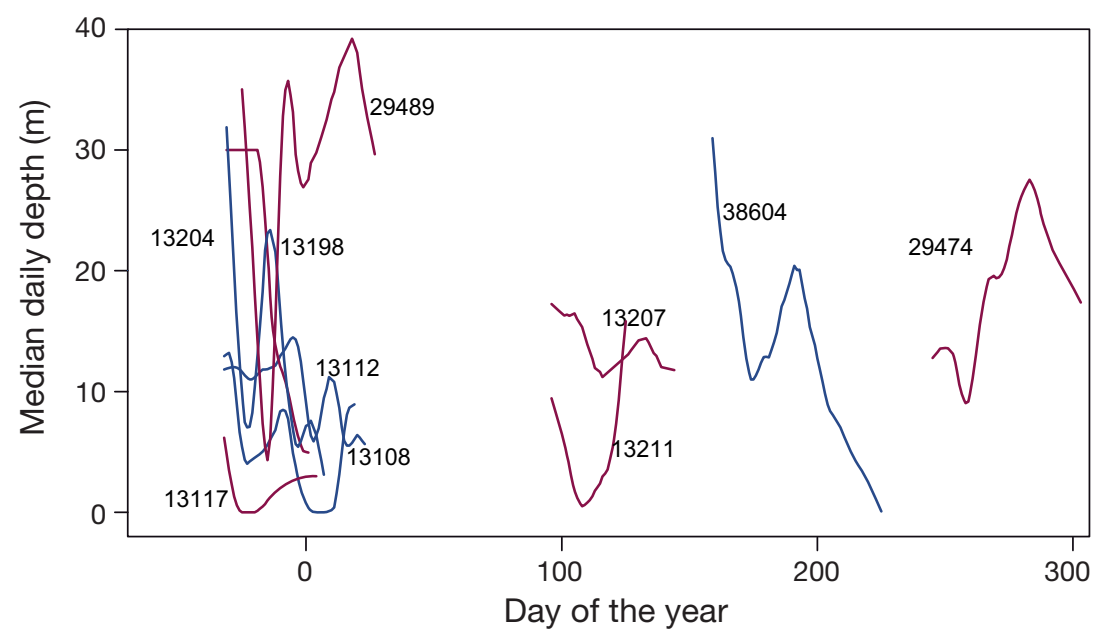

Fig. 4. Lepidochelys olivacea. Smoothed median daily depths of turtles by day of the year. Daily smoothed median depths are shown for 3 turtle groups: longlinecaught olive ridley turtles ( $\mathrm{n}=6$; red), olive ridley 'control' turtles ( $\mathrm{n}=4$; blue). For an explanation of numbers see Table 1 $30^{\circ} \mathrm{C}$ (Fig 5). Longline-caught turtles consistently ventured into colder water than control animals, in that the range of temperatures recorded for longlinecaught turtles $\left(10\right.$ to $\left.30^{\circ} \mathrm{C}\right)$ was broader than for control turtles $\left(13\right.$ to $30^{\circ} \mathrm{C}$; Fig. 3). Statistical comparisons of day vs. night temperature recordings revealed no differences between groups of control and longline-caught turtles either during the total time at liberty or during the first $30 \mathrm{~d}$ after release $(\mathrm{p}$ $>0.176$ and $p>0.993$, respectively). We therefore combined day and night temperature data. Fig. 6 hows that olive ridely turtles spent nearly $100 \%$ of

Because turtles were tagged over 3 consecutive years, we also investigated median daily depths and median daily water temperatures by day of the year to investigate potential seasonal effects on vertical movements (Figs. 4 \& 6). The depth and temperature associations of longline-caught or control turtles were both uniform throughout. One turtle, (\#29489, tagged in December 2002) exhibited a deeper median daytime distribution than all other turtles tracked during the same period in 2001 and 2002.

Only 1 turtle exhibited an effect of moon phase on dive behavior (\#29474). In this case, average depth of night dives correlated with a full moon $(r=0.55$, $\mathrm{p}<0.001$ ).

The one green turtle tagged was at liberty for 26 d before its PSAT was shed. The turtle spent $97 \%$ of the time within the top $50 \mathrm{~m}$ and it remained at shallower depths at night than during the day; $72 \%$ of recorded nighttime depths were within the top $10 \mathrm{~m}$. The turtle never descended below $100 \mathrm{~m}$. During the day, the turtle spent $47 \%$ of recorded time between 27.5 and $30.0^{\circ} \mathrm{C}$, and at night remained in warmer water ( $74 \%$ of the time was spent between 27.5 and $30.0^{\circ} \mathrm{C}$ ). The minimum day and night temperature recorded was 17 and $21.9^{\circ} \mathrm{C}$, respectively.

\section{Post-release mortality}

Of the 11 PSATs reporting data, we observed only one clear instance of a mortality event, and this was for a 'control' animal. This adult male olive ridley turtle (\#38604) was tagged on June 8, 


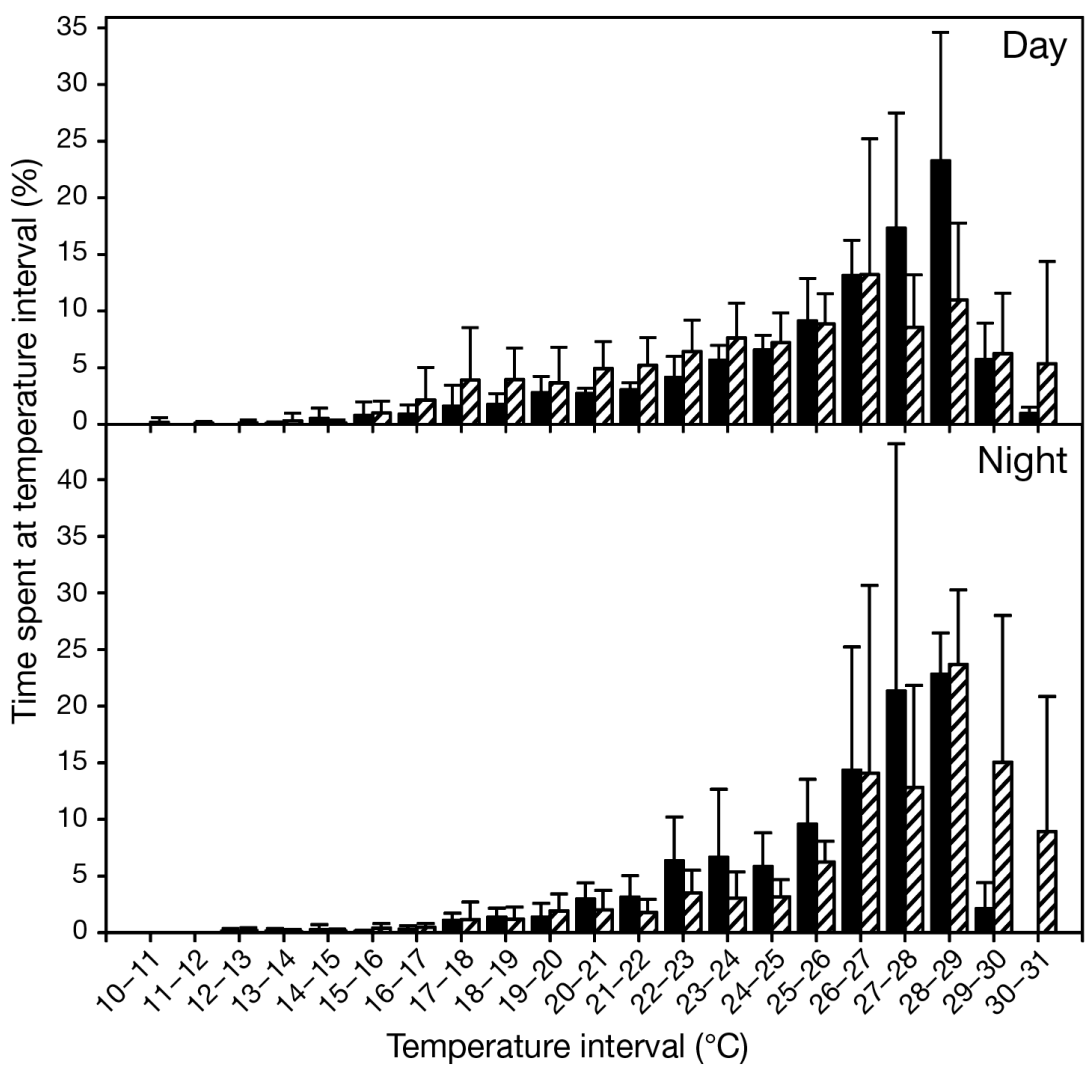

Fig. 5. Lepidochelys olivacea. Temperature distributions of 7 olive ridley turtles captured by longline fishing gear (filled bars) and 4 control turtles (striped bars)

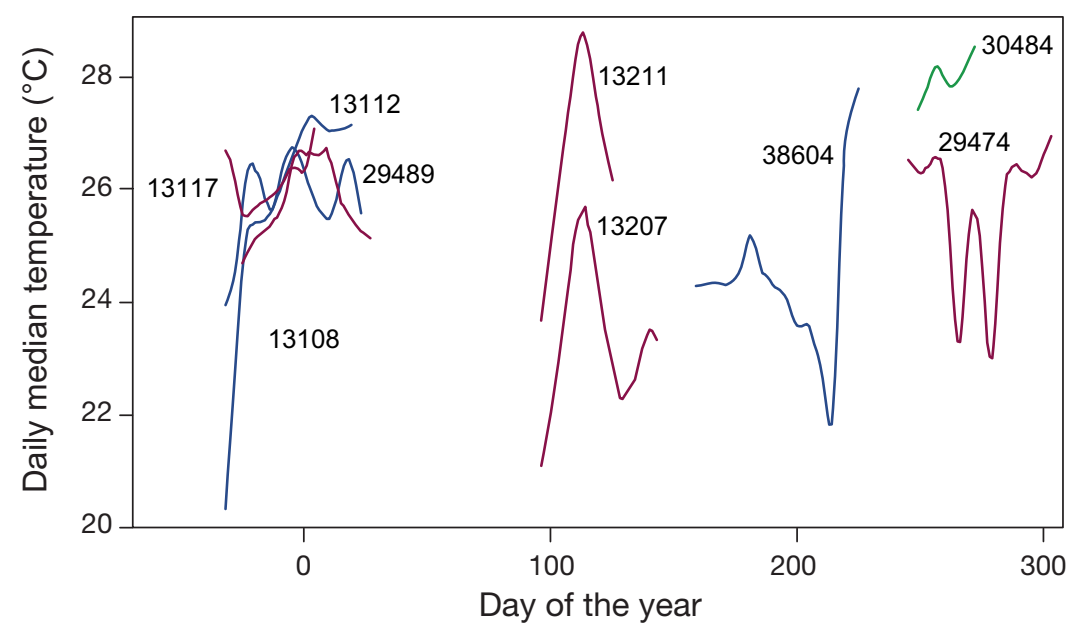

Fig. 6. Lepidochelys olivacea. Smoothed median daily water temperatures occupied by turtles by day of the year. Daily smoothed median depths are shown for 3 turtle groups: longline-caught olive ridley turtles $(n=6$; red), olive ridley 'control' turtles $(\mathrm{n}=4$; blue), longline-caught green turtle ( $\mathrm{n}=1$; green). For an explanation of numbers see Table 1

2003. Depth data show that the turtle sunk to the ocean floor (ca. $900 \mathrm{~m}$ depth) $66 \mathrm{~d}$ later on August 13, 2003 (Fig. 7).

\section{DISCUSSION}

\section{Tag performance}

Conventional platform terminal transmitters (PTTs), which are usually attached via layers of resin impregnated fiberglass cloth, have been repeatedly documented to stay attached to hardshelled turtles for longer than $1 \mathrm{yr}$ (Plotkin 1998, Polovina et al. 2004, Chaloupka et al. 2004). In contrast, although our PSATs were programmed to jettison from the animals 8 to 12 mo after deployment, tag retention averaged only $56 \mathrm{~d}$. We have no definitive explanation for this problem, but we are currently conducting a meta analysis of data from PSATs deployed on a range of pelagic animals to help elucidate key factors critical for tag retention times. However, in trials we conducted with captive green turtles, we found that PSATs attached with epoxy and syntactic foam base plates routinely remained attached for 8 to 12 mo (Swimmer et al. 2002). In the present study, we suspect that early tag shedding may be a result of tags becoming dislodged due to turtle-turtle interactions. The Gulf of Papagayo is an important breeding ground for the eastern Pacific population of olive ridleys, which nest either solitarily or in a massive synchronous nesting event known as an 'arribada', which involves hundreds to tens of thousands of nesting females from June through November (Clifton et al. 1982, Eckrich \& Owens 1995, Plotkin et al. 1996). Both males and females are known to assemble in large groups prior to (and possibly after) nesting (Plotkin et al. 1996). Thus, we feel that the highly social behavior of turtles may be the direct reason for premature tag shedding.

\section{Individual turtle tracks}

Graphic representation of depth and temperature data from PSATs of individual turtles over time appears to reveal the most complete story of habitat use among olive ridleys in the eastern tropical Pacific (ETP). As illustrated in Figs. $3 \& 4$, turtles from the same treat- 


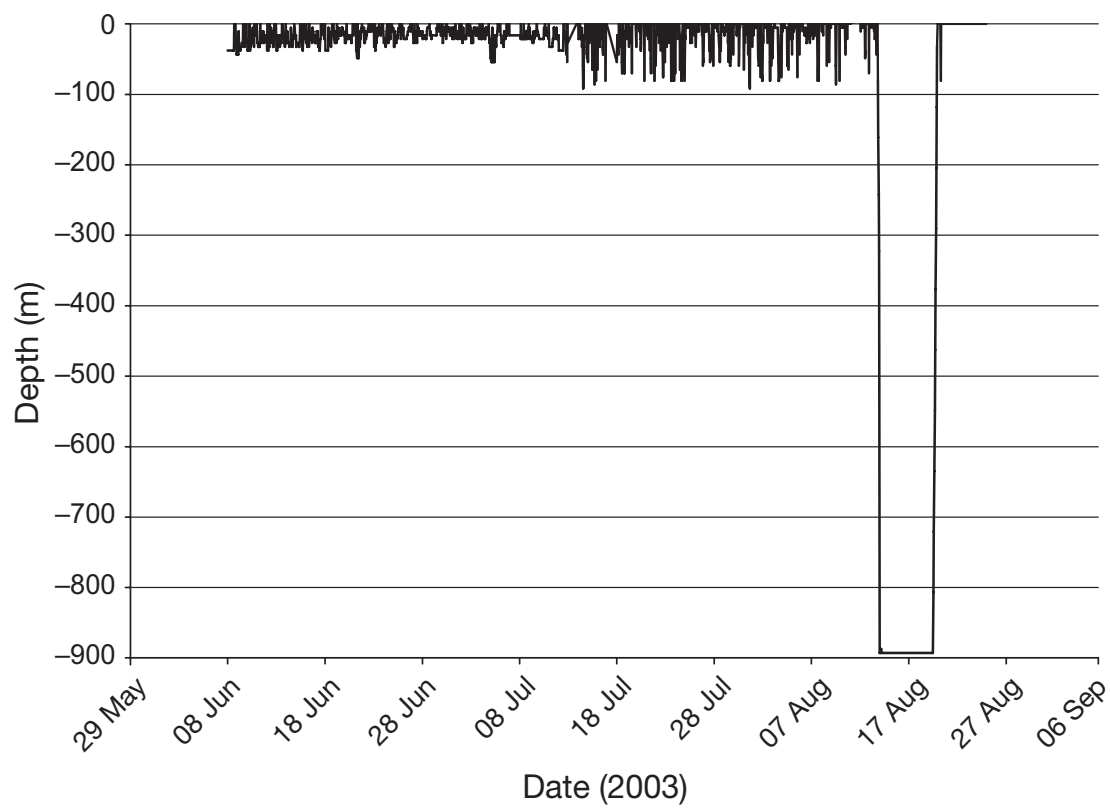

Fig. 7. Lepidochelys olivacea. Depth data for olive ridley turtle \# 38604 suggesting normal behavior after tagging on June 8, 2003, until it apparently died and sunk on Aug 13, 2003. The turtle and tag remained on the seafloor for $4 \mathrm{~d}$ after which the tag was released, floated to the surface, and began to transmit its data

way it is coupled with biological processes (e.g. chlorophyll production) has previously been described as playing a significant role in sea turtle distributions patterns (Polovina et al. 2004). Furthermore, the range of temperatures most frequently recorded by olive ridleys in the present study were nearly identical to the preferred thermal habitat defined for olive ridley turtles in the central North Pacific Ocean (23 to $-28^{\circ} \mathrm{C}$ ) (Polovina et al. 2004).

\section{Vertical movements}

From the histogram data (Fig. 2), it appears that longline-caught turtles spent more time at shallower depths and in warmer water during the day than control turtles. However, graphic presentation of individual turtles' depth data (inclusive of both tag types) suggest high variability within turtle groups, thereby limiting statistical

ment group (longline-caught) were recorded at both the shallowest and the deepest depth distributions, again suggesting little direct effect of fishery interactions. Additionally, turtles median depth by day of the year (Fig. 4) suggests similar depth distribution throughout the year, independent of season.

Although unsubstantiated statistically, our graphs suggest that turtles' depth distributions are influenced by water temperatures. Fig. 6 shows that all turtles (including \#29489 which exhibited deeper diving behavior than all other turtles tracked during the entire $3 \mathrm{yr}$ period, Fig. 4), spent nearly $100 \%$ of the time within a limited range of temperatures $\left(22\right.$ to $\left.-28^{\circ} \mathrm{C}\right)$. We postulate that deeper dives were a mechanism which enabled the turtles to remain within a temperature range that supports suitable prey items. Furthermore, we speculate that the deeper distribution recorded for turtle \#29489 was due to annual variations in oceanographic conditions, specifically sea surface temperature (SST) and chlorophyll, between years. In a $5^{\circ}$ radius area of investigation where all the turtles were tracked (centered at approximately $89^{\circ} \mathrm{W}$ and $10^{\circ} \mathrm{N}$ ), SST were approximately 1 to $4^{\circ} \mathrm{C}$ higher during 2002 and 2003 than in the previous $12 \mathrm{mo}$, with a corresponding decrease in surface chlorophyll a concentrations ranging from approximately $1.5-3.5$ to $0-0.5 \mathrm{mg} \mathrm{m}^{-3}$. Warmer sea surface temperatures during 2002 and 2003 appear responsible for the deeper dives of turtle \#29489, as these enabled this individual to maintain better contact with suitable prey. Sea surface temperature and the interpretation. Such comparisons between groups are further limited by working with a relatively small sample size. In brief, despite several different methods of data analysis, we found no differences suggestive of a turtle compromised as a result of the interaction with longline gear. As a caveat, however, we obviously cannot prove the null hypothesis: that the fishery interaction did not alter the behavior, growth, health, or reproductive potential of an animal.

We found that both groups had similar dive profiles with respect to frequency of time spent at various depths and associated water temperatures. A previous study on the effects of capture in longline fishing gear found that deeply-hooked and lightly hooked loggerhead turtles in the North Pacific had similar vertical and horizontal movement patterns (Parker et al. 2004). However, preliminary data on diving behavior of loggerhead turtles suggest that turtles made shallower dives immediately upon release from longline fishing gear.

In general, olive ridley turtles spent nearly all of the time recorded within the top $60 \mathrm{~m}$, with very few dives below $100 \mathrm{~m}$; this is similar to behaviors reported by Swimmer et al. (2002) and Polovina et al. (2002) for olive ridley turtles in the north Pacific Ocean. Turtles in the north Pacific, however, spent more time at greater depth than turtles we tracked in the ETP and also had deeper maximum dives (544 m vs. $408 \mathrm{~m}$ ) (Y. Swimmer, unpubl. data). The shallower distribution of turtles in the ETP is likely due to a permanent shallow thermo- 
cline $(20$ to $100 \mathrm{~m})$, as well as a number of surface currents and fronts rendering the upper layers productive, biologically diverse, and rich in suitable prey species (Wyrtki 1966). Polovina et al. (2002) speculated that the relatively deep distribution of olive ridley turtles in the north Pacific resulted from turtles' foraging on organisms associated with the deep scattering layer.

\section{Post-release mortality}

In the one case for which we have data indicating a mortality (\#38604, a control turtle), the PSAT performed exactly as expected. The depth record clearly showed that the turtle sank to the bottom $4 \mathrm{~d}$ before the tag jettisoned to the sea surface. We consider this event to be a natural mortality, although we can not rule out the possibility that the turtle subsequently interacted with longline fishing gear. The survivorship of olive ridleys in the ETP is unknown, but likely similar to estimated annual survivorship probabilities of green and loggerhead sea turtle populations, which range from 0.6 to 0.9 (Chaloupka \& Limpus 2002, Bjorndal et al. 2003a,b, Seminoff et al. 2003). Thus, a natural mortality in 1 of the 15 turtles we monitored over time could be expected.

By accepted definitions, all the longline-caught turtles except one were 'lightly hooked', as 'deep hooking' is characterized by a hook lodged in the gastrointestinal tract caudal to the glottis (Work \& Balazs 2002). Therefore, in all but one of the longline-caught turtles used in our study, hooks could be easily removed prior to release. The longline-caught turtles from which we received some PSAT data all survived a minimum of $3.5 \mathrm{wk}$, and most survived a minimum of $6 \mathrm{wk}$ postrelease before the tag was shed. Our results indicate, therefore, that lightly hooked olive ridley turtles survive their encounter with shallow-set longline fishing gear. We consider it unlikely that mortality events in lightly hooked turtles that occur 6 or more wk after release are a direct result of longline gear interaction. Because no turtles were excluded from the study due to an a priori assumption of well-being, we also contend that our findings reflect the impacts of light hooking in shallow-set gear on populations of olive ridley turtles in the ETP. We further contend that there is no reason to assume that transmission failures of the 3 non-reporting PSATs were due to mortality. PSATs deployed on pelagic fish can have high failure rates, with up to 70 to $80 \%$ of the tags deployed failing to report (M. Musyl \& R. Brill, unpubl. obs.).

Although our findings strongly suggest low rates of post-release mortality in lightly hooked olive ridley turtles caught by shallow-set longline fishing gear, we do not necessarily assume that other sea turtle species interacting with fishing gear show the same resilience. Poiner \& Harris (1996), reported that sea turtles incidentally caught in an Australian trawl fishery showed different rates of mortality, whereby hawksbill turtles Eretmochelys imbricate suffered the greatest mortality, and flatback turtles Natator depressa the lowest. Moreover, our results and conclusions are only applicable to shallow-set longline gear using circle hooks. Deep-setting longline gear and/or the use of J-hooks may drastically alter the predicted mortality of hooked or entangled marine turtles. Furthermore, the location and severity of hooking has been shown to influence probability of survivorship. Chaloupka et al. (2004) quantified post-release mortality for light and deep hooked loggerhead Caretta caretta turtles caught in a longline fishery by modeling time-to-failure of satellite transmitters. Their results indicate that mortality was higher in deeply hooked than in lightly hooked turtles during the first $90 \mathrm{~d}$ post-release, but that there were no differences in mortality rates after this time.

Because we only looked at post-release mortality on an individual level, we refrain from commenting on population-level effects, nor can we definitively conclude that turtles tagged after the fisheries interaction resumed normal breeding patterns. However, if most turtles indeed survive longline capture and release, we feel that there is no obvious reason to suggest that they did not resume normal breeding behavior.

\section{CONCLUSIONS}

Our data suggest that lightly hooked olive ridley turtles caught by shallow-set longline fishing gear survive these interactions for at least 2 mo after their release. Our results also suggest that turtles' movements are correlated with oceanographic variables (e.g. SST, chlorophyll concentration), which may result from the distribution of prey items. Therefore, a rise in sea surface temperatures due to El Niño events and climate variability will likely alter the movement patterns of marine turtle species.

Acknowledgements. We acknowledge extensive technical and administrative assistance from C. Boggs, D. Lau, R. M. Laurs, B. Oshiro, and J. Sibert. This project was funded by the University of Hawaii Pelagic Fisheries Research Program (Grant \#658847) and by the Pacific Islands Fisheries Science Center, NOAA National Marine Fisheries Service. All research was conducted in accord with the protocols and handling guidelines set forth by the University of Hawaii Animal Care and Use Committee (IACUC Protocol \# 00-037-2). M. Chaloupka and A. Southwood edited earlier drafts of this manuscript, but any errors of omission or commission are solely ours. Opinions expressed herein are of the authors only and do not imply endorsement by any agency associated with them. 


\section{LITERATURE CITED}

Aguilar R, Mas J, Pastor X (1995) Impact of Spanish swordfish longline fisheries on the loggerhead sea turtle Caretta caretta population in the western Mediterranean. In: Richardson JI, Richardson TH (eds) Proc 12th Annu Symp on Sea Turtle Biology and Conservation. NOAA Tech Mem NMFS-SEFSC-361, p 1-6

Arnold G, Dewar H (2001) Electronic tags in marine fisheries research: A 30-year perspective. In: Sibert J, Nielson J (eds) Electronic tagging and tracking in marine fisheries research: methods and technologies in fish biology and fisheries, Vol 1. Kluwer Academic Press, Dordrecht, p 7-64

Bjorndal KA, Bolten AB, Chaloupka MY (2003a) Survival probability estimates for immature green turtles Chelonia mydas in the Bahamas. Mar Ecol Prog Ser 252:273-281

Bjorndal KA, Bolten AB, Martins HR (2003b) Estimates of survival probabilities for oceanic-stage loggerhead sea turtles (Caretta caretta) in the North Atlantic. Fish Bull 101:732-736

Chaloupka MY, Limpus CJ (2002) Survival probability estimates for the endangered loggerhead sea turtle resident in southern Great Barrier Reef waters. Mar Biol 140:267-277

Chaloupka M, Parker D, Balazs GH (2004) Modeling postrelease mortality of pelagic loggerhead sea turtles exposed to the Hawaii-based longline fishery. Mar Ecol Prog Ser 280: 285-293

Clifton K, Cornejo DO, Felger RS (1982) Sea turtles of the Pacific coast of Mexico. In: Bjorndal KA (ed) Biology and conservation of sea turtles. Smithsonian Institution Press, Washington, DC, p 199-209

Eckrich CE, Owens DW (1995) Solitary versus arribada nesting in the olive ridley sea turtles (Lepidochelys olivacea): a test of the predator-satiation hypothesis. Herpetologica 51(3): 349-354

Epperly S, Prince EP, Bolten A (2002) Development of an experimental design and research plan to estimate posthooking survival of sea turtles captured in pelagic longline fisheries. In: Watson J, Foster D, Epperly S, Shah A (eds) Experiments in the western Atlantic northeast distant waters to evaluate sea turtle mitigation measures in the pelagic longline fishery. NOAA Fisheries, Southeast Fisheries Science Center Report, May 2002

Ferreira RL, Martins HR, Silva AA, Bolten AB (2001) Impact of swordfish fisheries on sea turtles in the Azores. Arquipelago 18A:75-79

Graves JE, Luckhurst BE, Prince ED (2002) An evaluation of pop-up satellite tags for estimating post release survival of blue marlin (Makaira nigricans) from a recreational fishery. Fish Bull 100:134-142

Gunn J, Block B (2001) Advances in acoustic, archival and satellite tagging of tunas. In: Block BA, Stevens ED (eds) Fish Physiology Series, Vol 19, Tuna physiology, ecology, and evolution. Academic Press, New York, p 167-224

Hays GC, Broderick AC, Godley BJ, Luschi P, Nichols WJ (2003) Satellite telemetry suggests high levels of fishing induced mortality in marine turtles. Mar Ecol Prog Ser 262:305-309

Hays GC, Broderick AC, Godley BJ, Luschi P, Nichols WJ (2004) Tracking turtles to their death. Mar Ecol Prog Ser 283:299-300

Lutcavage ME, Lutz PL (1997) Diving Physiology. In Lutz PL,

Editorial responsibility: Kenneth Sherman (Contributing Editor), Narragansett, Rhode Island, USA
Musick JA (eds) The biology of sea turtles. CRC Press (CRC Marine Science Series), Boca Raton, FL, p 277-296

Lutcavage ME, Brill RW, Skomal GB, Chase BC, Howey PW (1999) Results of pop-up satellite tagging of spawning size class fish in the Gulf of Maine: Do North Atlantic bluefin tuna spawn in the mid-Atlantic? Can J Fish Aquat Sci $56: 173-177$

McCracken ML (2000) Estimation of sea turtle take and mortality in the Hawaiian longline fishery. NOAA-TECH MEMO-SWFSC-H-00-06

Parker DM, Balazs GH, Murakawa SKK, Polovina JJ (2004) Post-hooking survival of sea turtles taken by pelagic longline fishing in the North Pacific. In: Coyne M (ed) Proc 21st Annu Workshop on sea turtle biology and conservation, February 24-28, 2001, Philadelphia, PA. NOAA Tech Memo NMFS-SEFSC-528

Plotkin PT (1998) Interaction between behavior of marine organisms and the performance of satellite transmitters: a marine turtle case study. Mar Technol Soc J 32(1): 5-10

Plotkin PT, Owens DW, Byles RA, Patterson R (1996) Departure of male olive ridley turtles (Lepidochelys olivacea) from a nearshore breeding ground. Herpetologica 52(1):1-7

Poiner IR, Harris AM (1996) Incidental capture, direct mortality and delayed mortality of sea turtles in Australia's northern prawn fishery. Mar Biol 125: 813-825

Polovina JJ, Kobayashi DR, Parker DM, Seki MP, Balazs GH (2000) Turtles on the edge: movement of loggerhead turtles (Caretta caretta) along oceanic fronts, spanning longline fishing grounds in the central North Pacific, 1997-1998. Fish Oceanogr 9:71-82

Polovina JJ, Howell E, Parker DM, Balazs GH (2002) Dive depth distribution of loggerhead (Caretta caretta) and olive ridley (Lepidochelys olivacea) sea turtles in the central North Pacific: Might deep longline sets catch fewer turtles? Fish Bull 101(1):189-193

Polovina JJ, Balazs GH, Howell EA, Parker DM, Seki MP, Dutton PH (2004) Forage and migration habitat of loggerhead (Caretta caretta) and olive ridley (Lepidochelys olivacea) sea turtles in the central north Pacific Ocean. Fish Oceanogr 13(1):36-51

Seminoff J, Jones T, Resendiz A, Nichols W, Chaloupka M (2003) Monitoring green turtles (Chelonia mydas) at a coastal foraging area in Baja California, Mexico: using multiple indices to describe population status. J Mar Biol Assoc UK 83:1355-1362

Spotila JR, Reina RD, Steyermark AC, Plotkin PT, Paladino FV (2000) Pacific leatherback turtles face extinction. Nature 405:529-530

Swimmer YJ, Brill RW, Musyl M (2002) Use of pop-up satellite archival tags to quantify mortality of marine turtles incidentally captured in longline fishing gear. Mar Turtle Newsl 97:3-7

Witzell WN (1999) The incidental capture of sea turtles by the U.S. pelagic longline fleet in the Western Atlantic Ocean. In: Williams P, Annino PJ, Plotkin P, Salvini KL (eds) Pelagic longline fishery interactions: Proceedings of an industry, academic and government experts, and stakeholders workshop, Silver Spring, MD, 24-25 May 1994, NOAA Tech Memo NMFS-OPR-7

Work TM, Balazs GH (2002) Necropsy findings in sea turtles taken as bycatch in the North Pacific longline fishery. Fish Bull 100:876-880

Wyrtki K (1966) Oceanography of the eastern equatorial Pacific Ocean. Oceanogr Mar Biol Annu Rev 4:33-68

Submitted: May 18, 2005; Accepted: December 9, 2005

Proofs received from author(s): September 20, 2006 